\title{
Effect of Chemical Composition on Hard Deposits Properties in the Case of Weld Refurbishment of Heavy Crushing Hammers
}

\begin{abstract}
DELIA GARLEANU ${ }^{1}$, GABRIEL GARLEANU²*
IUniversity Politehnica of Bucharest, Materials Science and Engineering Systems Faculty, Materials Technology and Welding Department, 313 Splaiul Independentei, 060042, Bucharest, Romania

University Politehnica of Bucharest, Engineering and Management of Technological Systems Faculty, Materials Technology and Welding Department, 313 Splaiul Independentei, 060042, Bucharest, Romania

The article presents a study on the influence of chemical composition on the hardness and microstructural properties in case of crushing hammers used in stone quarries that can be refurbishment by welding, using different types of filler material. In this research paper it is analyzed the effect that chemical composition of the filler material exerts on the microstructure of the loading area, the dilution effects at the welding interfaces level and the modification of the microhardness. Three types of filler material with different chemical composition have been used in order to choose the optimal version that ensures the best performance in operation.
\end{abstract}

Keywords: chemical composition, diffusion, hardfacing, welding, microstructure, microhardness

An effective and often used method for restoring the geometrical characteristics of rock processing equipment is hardfacing [1-4, 18-21]. In this case, different types of filler material are used to hardfacing the areas affected by wear phenomena. The chemical composition of the filler materials is chosen according to the type of stresses [4 and 5], the technological processes [6-9], the mechanical and technological characteristics required in operation, economic and endurance considerations, etc. When make hardfacing with alloys having a chemical composition different from that of the base material, it is important to limit the dilution effects and the decrease in the concentration of the chemical elements in the hard deposits. Technological solutions are chosen to reduce the mutual diffusion effects of strongly carburized elements $(\mathrm{C}, \mathrm{Cr}, \mathrm{Ti}, \mathrm{Mo}, \mathrm{V})$, which tend to accumulate on the grain boundaries with the formation of hard and fragile areas, either by deposition of nickel rich buffer layers, or by limiting the heat input level in the welding area [5-10]. In order to obtain adequate impact wear resistance properties, it is necessary to deposit layers with hardness at least equal to that of the base material, which may eventually become additionally hardened during operation [11].

The geometric characteristics and the microstructure of hard deposits are strongly influenced by the parameters of the welding system and by the chemical composition of the filler materials [12], through the carbides' particles morphology and sizes [13] or the tendency of occurrence of some dendritic segregation [14].

The crushing hammers analyzed in this research paper are massive castings, intensively used in the quarry stones processing plants. For such an application, manganese steel which has self-cold-work hardening properties during operation is usually used. The main stresses that the crushing hammers are subjected to are the dynamic impact resulting from the rotation movement and the friction abrasion with different pieces of stone having various dimensions. As contact surfaces become worn during operation, thus altering the size of the crushed stone grain, periodic refurbishing activities are required by welding loads on the worn areas or by replacing the decalibrated pieces. The heavy hammers are exposed to various types of mechanical stresses such as: impact, compression, stretching, friction, bending, wear etc., but major effects on the use characteristics have the dynamic impact in rotation combined with the severe abrasion caused by the friction with the stone breaks [22-24]. As a result of these stresses, after a certain period of use, the wear of some work areas occurs, requiring either the replacement of the used parts with new ones or the refurbishment through welding loads [15-22].

The chemical composition and the mechanical properties of the materials from which the crushing hammer is made are selected according to the actual operating conditions, the type of rock and the final size of the ground products. Due to reasons of economic nature, they are often made of steel with high content of $\mathrm{Mn}$, alloyed with $\mathrm{Cr}$ and $\mathrm{Si}$, which is or it is not subjected to thermal treatments. The initial hardness value should be in the 200$300 \mathrm{HB}$ range. After the cold-work hardening, the hardness value may increase up to values ranging from 450 to 550 $H B$. At the same time, a finite element computerized program was used, using both the initial data from the machine operation and the endurance testresults, in order to determine the good functioning range of the components hard faced, depending on the chemical composition of the deposited metal. The chosen welding process was GMAW (Gas Metal Arc Welding) using solid wire and full carbon dioxide protection. From the microhardness measurements it was found that the value of the hardness of the deposited material is influenced by the chemical composition and the cold-w ork hardening time during operation.

Likewise, the microstructural aspects highlight the transformations occurring at the interface between the two welded materials, the location of the micro-cracks, the mutual diffusion distance of the chemical elements and the penetration depth of the welded deposit [24-25]. The major advantage of using this hardfacing technology is the ability to welding without displacement of the crushing hammers from the working area, as well as increasing the operational life of about 2 to 3 times. 


\section{Experimental part}

The crushing hammer with a maximum size of $500 \times 500 \times 300 \mathrm{~mm}$ (fig. 1), used for primary breaking and grinding of stones, is analyzed in this research paper. The weight of the crushing hammers varies between 10 and $200 \mathrm{Kg}$ depending on the stone processing equipment. From the images shown in figure 1 there may be observed the rounding effects of the edges of the hammers due to the erosive effects at the contact with the processed materials.

Depending on the construction version, if the active part of the hammer is detachable, it can be quickly replaced with a new one by stopping the machine for a short period of time. However, if the hammer is built in the mono-bloc version, by casting followed the heat treatment, it has to be completely replaced, which means higher costs, or it can be loaded by welding at the place of installation, using hard material.

The application analyzed in the research paper refers to a hammer with an initial weight of $125 \mathrm{Kg}$, which, after wear, reaches about $115 \mathrm{Kg}$, with a weight loss of about $10 \mathrm{Kg}$. The operational life can be between 4 to 6 months, depending on the type of the stone being processed, its shape and its geometrical dimensions. The main wear occurs in this type of hammer in the active area 1 (fig. 1a), on the attack edge at which the initial angle value is of $90^{\circ}$. During operation, due to the rotating speed of $800 \mathrm{rpm}$ and repeated strikes against the vivid edges stone brans, this area is being rounded. If the curvature radius value of the edge exceeds $10 \mathrm{~mm}$, in order to maintain the required value for the gravel grain, the moving jaws of the crusher are displaced. This adjustment can only be made until the crushing hammer connection beam has reached $40 \mathrm{~mm}$ (fig. 1b), the little hammers being changed after approximately 3000 hours of operation. The most costeffective solution to solve the problem is the hardfacing, since casting and heat treatment operations are no longer required. Additionally, it is not necessary to dismantle the massive parts, and thus the time of interruption of the production process is much shorter. The material from which the crushing hammer is made is manganese steel of T130M135 type whose chemical composition is shown in table 1. The main mechanical characteristics provided by the material's manufacturer are: Tensile strength 1130 $\mathrm{MPa}$, Yield strength $390 \mathrm{MPa}$, Hardness after cold-working 400 - $450 \mathrm{HV}$. At the moment, the technology of refurbishment through welding does not apply to the beneficiary, the used crushing hammers being regularly replaced and sent to the recycling companies.

According Schaeffler diagram prediction [17, 24], for an estimated value of dilution of $30 \%$, the calculated values for Chromium equivalent and Nickel equivalent are the follows: for base metal $-\mathrm{Cr}_{(\mathrm{eq})}=2.55 \% \mathrm{wt}$. and $\mathrm{Ni}_{\text {eq) }}=43.82 \%$ wt.; for welding consumable MF 7-200KN $\mathrm{Cr}^{\text {(eq) }}=4 \% \mathrm{wt}$. and $\mathrm{Ni}_{\text {in }}=37.6 \%$ wt.; for welding consumable MF $7-250-\mathrm{KN} P-\mathrm{Cr}_{\text {ea }}=15.35 \% \mathrm{wt}$. and $\mathrm{Ni}_{\text {(eq) }}=21.20 \% \mathrm{wt}$.; for welding consumable MF 6-60-PGT $\mathrm{Cr}_{(\mathrm{eq})}^{(\mathrm{eq})}=13.70 \% \mathrm{wt}$. and $\mathrm{Ni}_{(\mathrm{eq})}=23.30 \% \mathrm{wt}$.

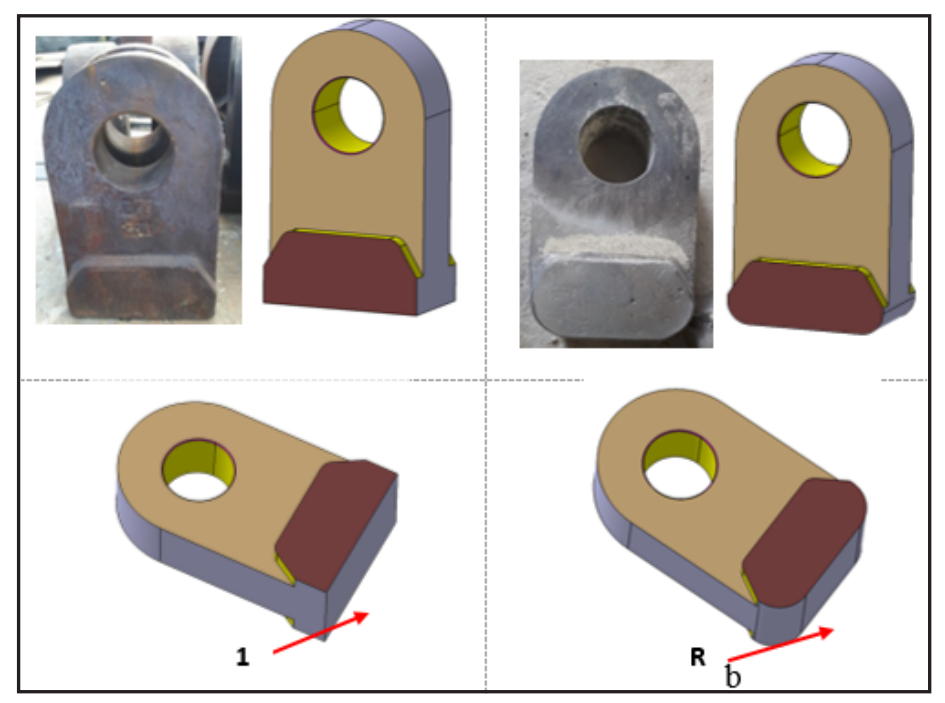

Fig. 1. The appearance of the crushing hammers a)Initial (unused) version; b) After working (wear producing rounded edges)

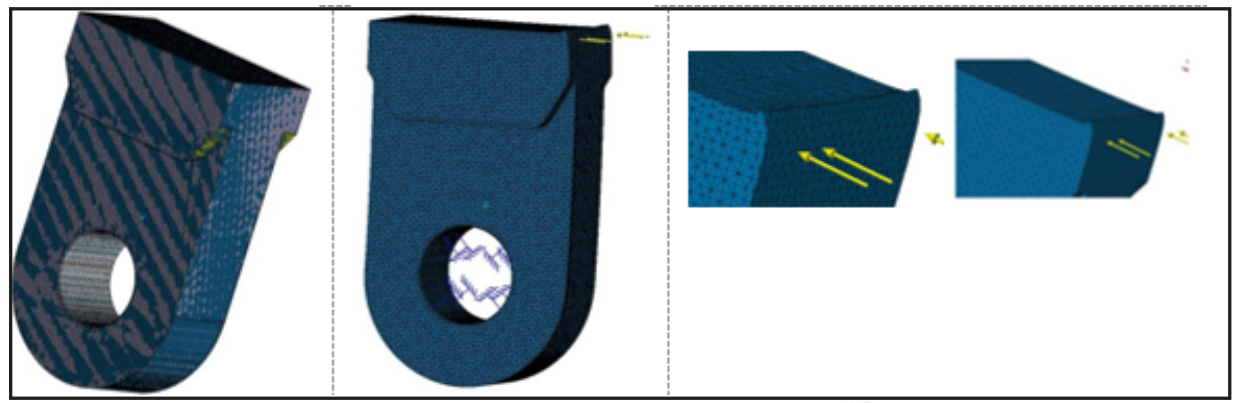

Fig. 2. Finite element analysis of the crushing hammer

a) Computerized crushing hammer in finite elements; b) Crushing hammer with forces applied on the impact edges; c) Deformation and flow of the impact edge

Table 1

THE MAIN CHEMICAL COMPOSITION OF THE CRUSHING HAMMER STEEL, \%wt

\begin{tabular}{|c|c|c|c|c|c|c|c|c|c|}
\hline & \multicolumn{9}{|c|}{ Chemical elements } \\
\hline & $\mathrm{C}$ & $\mathrm{Si}$ & $\mathrm{Mn}$ & $\mathrm{Cr}$ & Mo & $\mathrm{Ni}$ & Al & V & $\mathrm{Cu}$ \\
\hline $\begin{array}{l}\text { Value according to } \\
\text { the product's } \\
\text { specification }\end{array}$ & 1.23 & 0.71 & 13.5 & 1.44 & 0.05 & 0.17 & 0.005 & 0.05 & 0.12 \\
\hline $\begin{array}{l}\text { Established through } \\
\text { spectrometric } \\
\text { analysis }\end{array}$ & $\begin{array}{c}1.2- \\
1.4\end{array}$ & $0.5-1$ & $\begin{array}{c}12.5- \\
14.5\end{array}$ & $\begin{array}{c}1.2- \\
1.5\end{array}$ & $\begin{array}{c}0.04- \\
0.05\end{array}$ & $\begin{array}{c}0.15- \\
0.18\end{array}$ & 0.005 & 0.02 & $\begin{array}{c}0.11- \\
0.12\end{array}$ \\
\hline
\end{tabular}


According to the calculated values from the Schaeffler diagram, in all three of the analyzed situations, the microstructure of the welded material is full austenitic. In order to ensure a good correlation between the data provided by the metallographic analyzes and the actual operating conditions, the finite element method for the analysis of the dynamical stress degree was used [15]. At the same time, the hammers loaded with different types of filler materials were put into service and monitored for the estimation of the good working time. In the framework of the finite element method analysis (FEM), a simulation of the dynamic load on the hammer attack areas was carried out, by applying virtual stresses on the impact edges (fig. 2).

To the crushing hammer, whose computerized representation is shown in figure $2 \mathrm{a}$, were applied striking forces strict on the working areas (Figure 2b), then the values of deformation and of the flow in solid state were determined (fig. 2c). Analyzing the three types of filler material chosen for the refurbishment of the worn-outareas of the crushing hammer, differences were observed in the behavior to dynamic shock of repeated impact, with a 100 hours running cycle (fig. 3).

Thus, it is found that for the same values of the impact energy, the distortion is very low in case of using a filler material of the type MF $7-200 \mathrm{KN}$ alloy (about $0.086 \mathrm{~mm}$ ) compared to version 2 (MF 7-250-KNP alloy) at which the distortion is $0.04 \mathrm{~mm}$ or version 3 (MF 6-60-PGT alloy), at which the distortion is more than 2.8 times higher. At the same time, an increase in the Von Mises equivalent tensile stress value from $4.25-21.2 \mathrm{Kgf} / \mathrm{cm}^{2}$ is observed.

\section{Hardfacing process}

The hardfacing on a manganese steel piece should be done with great care, using a filler material to achieve high mechanical, impact and abrasion resistance properties that have chemical, metallurgical and mechanical compatibility with the supporting material $[16,22]$. For the application presented in this research paper, three filler materials wire-type were chosen for the hardfacing by welding using GMAW process. There is also the possibility of using coated electrodes with equivalent chemical composition, butfor productivity reasons ithas been chosen to use the GMAW process, which provides a metal deposit of about 4 - 5 times faster than manual welding.

The technical problems solved by the refurbishment technology through welding are: restoring of the impact area profile of the crushing hammers, reducing the work cut-off time and reducing the cost of remediation of the wear effects. The filler materials used in this study were bearing the following trademarks: MF 7-200 KN; MF 7-250KNP; MF 6-60-PGT, whose chemical compositions are indicated in table 2. The hardness values guaranteed by the suppliers of the filler materials for the 3 (three) versions of full welding wire are indicated in table 3.

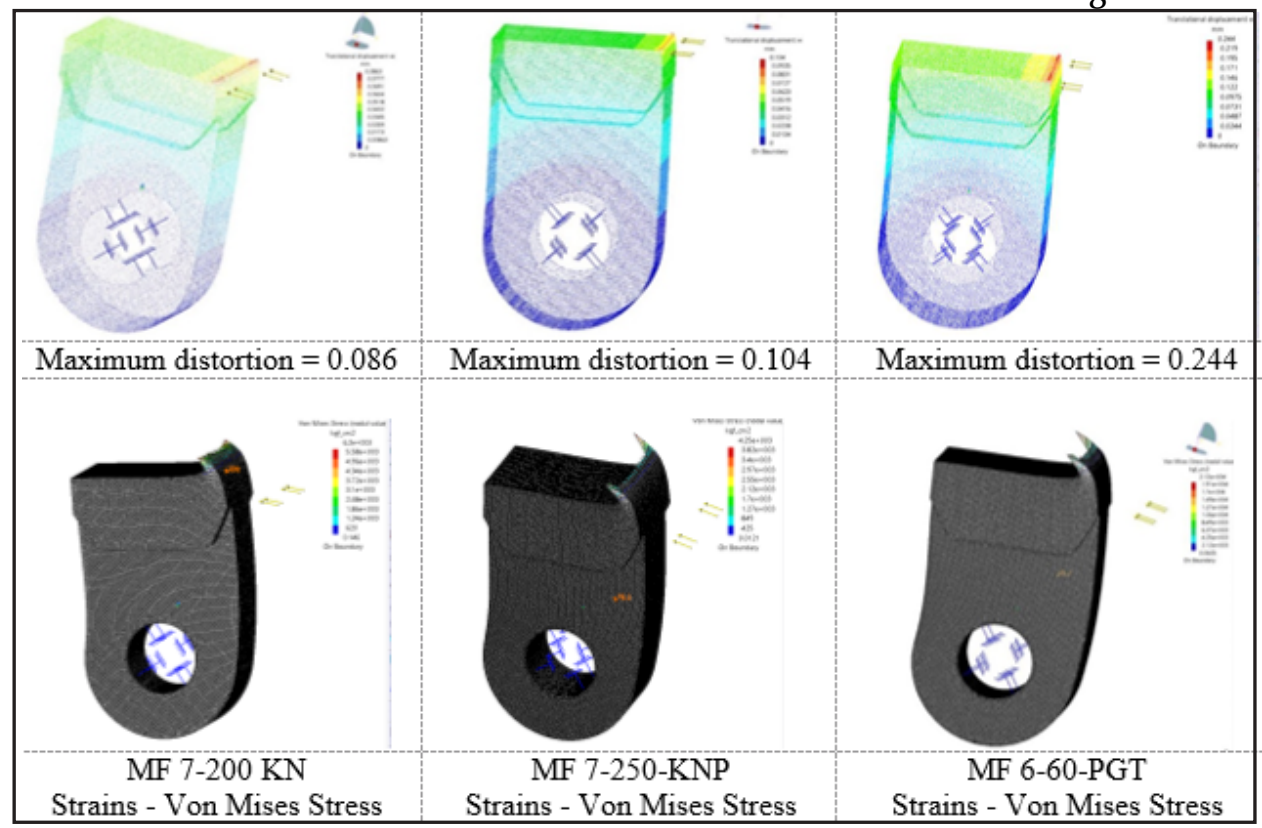

Fig. 3. Variation of Von Mises distortions and strain-stress for the three types of analyzed filler material

\begin{tabular}{|l|c|c|c|c|c|c|c|c|}
\hline \multirow{2}{*}{} & \multicolumn{9}{|c|}{ Chemical elements } \\
\cline { 2 - 9 } & $\mathrm{C}$ & Mn & Si & Cr & Ni & Mo & V & Fe \\
\hline MF 7-200 KN & 1 & 14 & - & 4 & 0.6 & - & - & Balance \\
\hline MF 7-250-KNP & 0.4 & 16 & 0.5 & 14 & 1.2 & 0.6 & 0.2 & Balance \\
\hline MF 6-60-PGT & 0.5 & 0.8 & 2.8 & 9.5 & 0.3 & - & - & Balance \\
\hline
\end{tabular}

Table 2

CHEMICAL COMPOSITIONS OF THE FILLER MATERIALS USED FOR HARDFACING, $w t \%$

\begin{tabular}{|c|c|c|}
\hline \multirow{2}{*}{ Wire trademark } & \multicolumn{2}{|c|}{ Hardness values } \\
\cline { 2 - 3 } & As deposited metal & After cold-work hardening \\
\hline MF 7-200 KN & $200-230 \mathrm{HB}$ & $400-450 \mathrm{HB}$ \\
\hline MF 7-250-KNP & $200-250 \mathrm{HB}$ & $450-500 \mathrm{HB}$ \\
\hline MF 6-60-PGT & $56-57 \mathrm{HRC}$ & - \\
\hline
\end{tabular}

Table 3

HARDNESS VALUES OF THE HARD-FACED ZONES 
Table 4

VALUES OF THE WELDING PARAMETERS FOR THE HARDFACING OF THE CRUSHING HAMMERS

\begin{tabular}{|c|c|c|c|c|c|c|c|}
\hline \multirow[t]{2}{*}{ Wire trademark } & \multicolumn{7}{|c|}{ Welding parameters } \\
\hline & $\begin{array}{c}\text { Current } \\
\text { intensity, Is, } \\
\text { A }\end{array}$ & $\begin{array}{c}\text { Tension, } \\
\text { Us, } \\
\text { V }\end{array}$ & $\begin{array}{l}\text { Gas } \\
\text { flow, } \\
\text { limin }\end{array}$ & $\begin{array}{c}\text { Filler } \\
\text { material } \\
\text { diameter, } \\
\mathrm{mm}\end{array}$ & $\begin{array}{l}\text { Welding } \\
\text { velocity, } \\
\mathrm{cm} / \mathrm{min}\end{array}$ & $\begin{array}{c}\text { Interlayers } \\
\text { temperature, } \\
{ }^{\circ} \mathrm{C}\end{array}$ & $\begin{array}{c}\text { Preheating } \\
\text { temperature, }{ }^{\circ} \mathrm{C}\end{array}$ \\
\hline MF7-200 KN & 210 & 20 & 15 & 1.2 & $30-40$ & 200 & 240 \\
\hline MF 7-250-KNP & 180 & 19 & 15 & 1.2 & $30-40$ & 200 & - \\
\hline MF 6-60-PGT & 200 & 20 & 15 & 1.2 & $30-40$ & 200 & - \\
\hline
\end{tabular}

The hardening effects are noted during operational requirements by the doubling of the hardness values for the first two filler materials. The welding parameters used to hardfacing the crushing hammers are indicated in table 4. Approximately equal values for electrical and technological parameters were selected, the only major difference being for the pre-heating temperature set at $240^{\circ} \mathrm{C}$ for the first filler material only.

\section{Results and discussions}

\section{Microstructure}

In order to perform the microstructural analysis, crosssections of the hard-faced samples by welding were obtained by cutting with the abrasive disc under cooling fluid. The selected samples were then subjected to the metallographic preparation procedure, which involves grinding with abrasive paper of progressive grains ( 320 to 1000 grit paper), polishing with abrasive powders (between 6 and $0.3 \mu \mathrm{m}$ ) followed by a chemical attack with $2 \%$ Nital reagent.

The metallographic prepared surfaces were examined using Olympus GX51 optical microscope equipped with Software AnalySis for image processing and with SEM Inspect S FEl electronic scanning microscope, equipped with a ZZe type EDS element detector system. The base material of the crushing hammers is a steel highly alloyed with $\mathrm{Mn}$ (over $12 \%$ wt. $\mathrm{Mn}$ ) and a high $\mathrm{C}$ content (above $1.2 \%$ wt. C), which results in a microstructure consisting of alloyed austenite, pearlite and complex carbides (fig. 4).

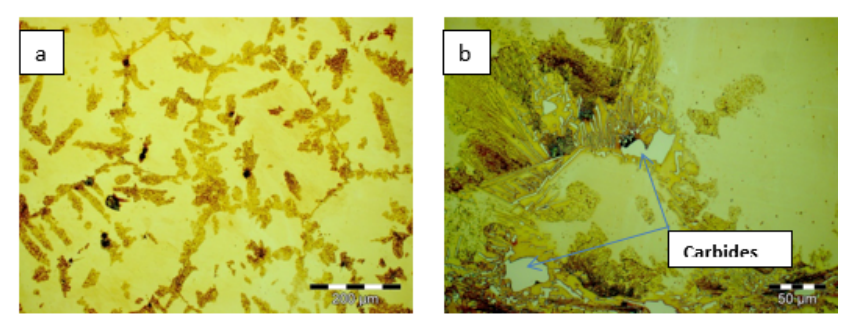

Fig. 4. Microstructure of the base material of the crushing hammers. The matrix contains austenite highly alloyed with $\mathrm{Mn}$, with elongated formations of lamellar pearlite (a) and precipitations of complex intermetallic carbides surrounded by pearlite islands (b)

In the case of the sample loaded with filler material of MF 7-200 KN type, the interface between the metal deposited through welding (WD) and the base material (MB) is delineated by a narrow area where segregation of intermetallic compounds occurred (fig. 5a). The heat affected zone (HAZ) is relatively narrow (thickness of about $600 \mu \mathrm{m}$ ) and no imperfections like cracks type are present (fig. 5b). It is observed a slight increase in granulation in the base material in the immediate vicinity of the fusion line (FL).

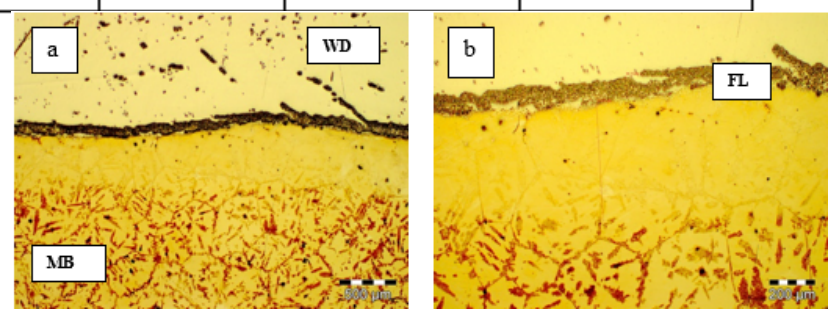

Fig. 5. The transition area between the metal deposited through welding and the base material when using filler material of MF 7-200 KN type

In the case of the sample loaded with filler material of MF 7-250 KNP type, at the interface between the two materials, it is observed the same tendency to segregate of some intermetallic compounds (fig. 6a), but this time in the form of dispersed islands, in some zones interrupted by cracks starting from the heat-affected zone of the base material towards the weld (Cr-rich alloyed steel) (fig. 6b).
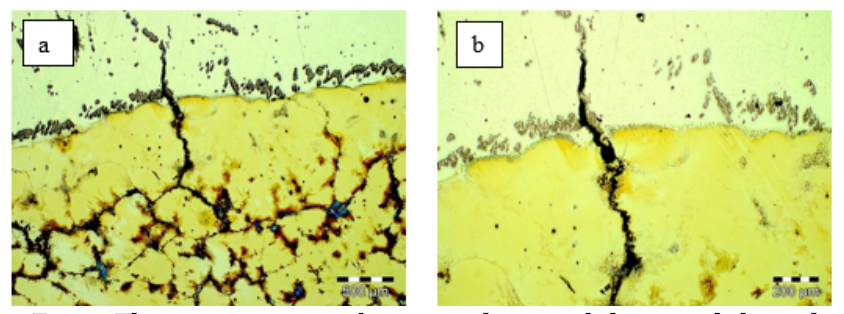

Fig. 6. The transition area between the metal deposited through welding and the base material in case of using filer material of MF 7-250 KNP type

At the same time, there are observed intergranular cracking and corrosion effects in the area under the stitching, about $1 \mathrm{~mm}$ below the fusion line.

The situation is even less favorable in the case of the sample loaded with filler material of MF 6-60-PGT type, where the cracking effects under the stitch are more pronounced (fig. 7).
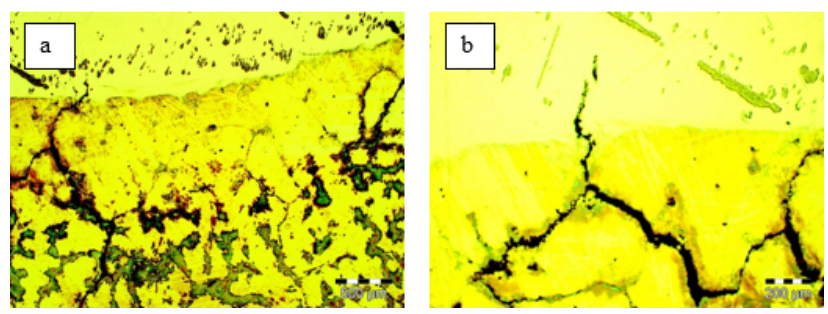

Fig. 7. The transition area between the metal deposited through welding and the base material in case of using filer material of MF 6-60-PGT type

Also in this case, the cracks are formed on the grain boundaries, extending towards the deposited material. The intermetallic compounds in the fusion line area are finer, in much smaller quantities and dispersed in the area of the loading $\mathrm{Cr}$-rich material. 
After the metallographic analysis, detailed analyzes were performed over the transition area between the welding and the base material, in order to assess the diffusion effects of the main chemical elements (fig. 8).
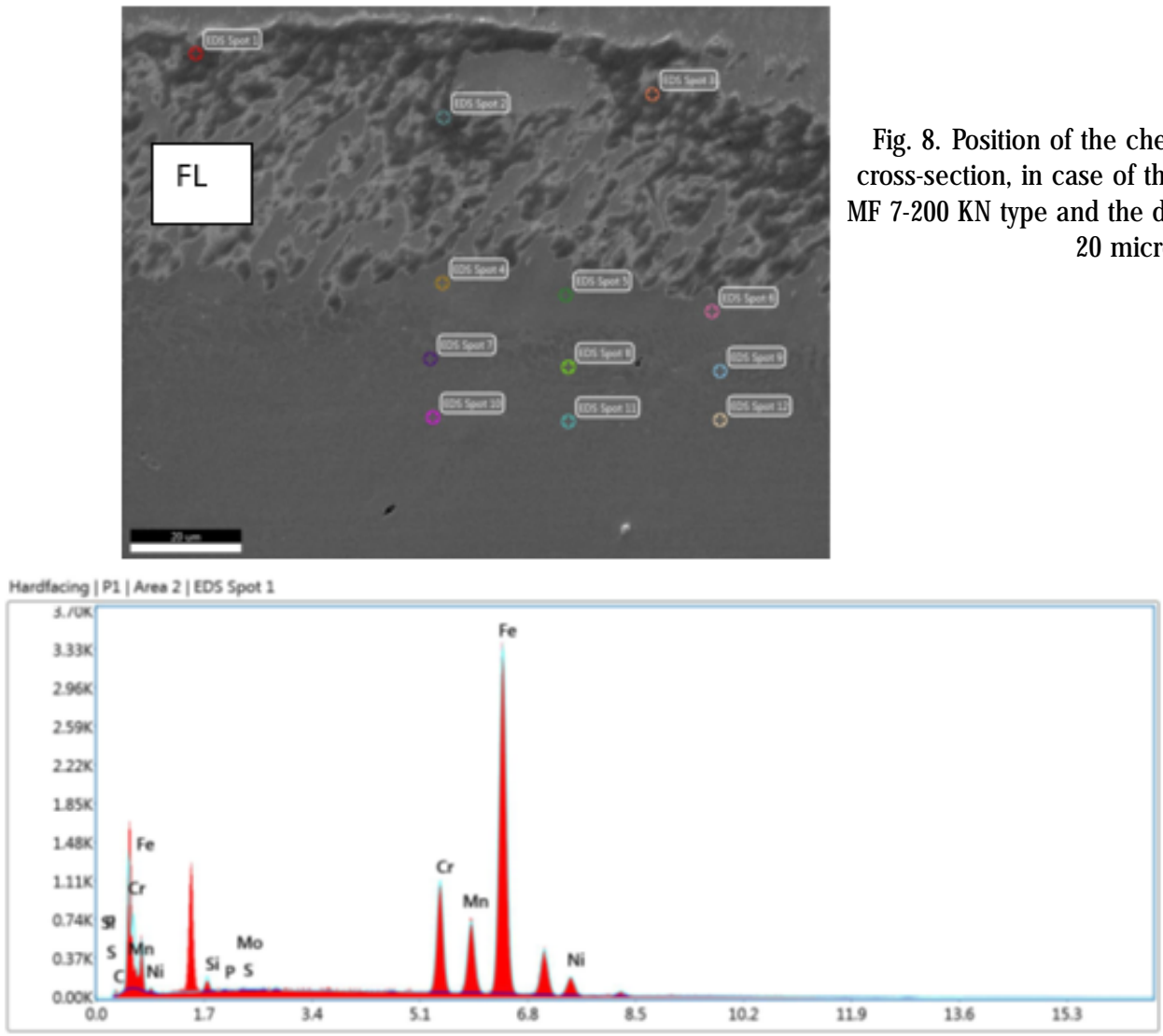

Table 5

CHEMICAL COMPOSITION IN DIFFERENT POSITIONS VERSUS FUSION LINE IN THE CASE OF MF 7-200 KN FILLER MATERIAL, \%Wt

\begin{tabular}{|l|c|c|c|c|c|c|c|}
\hline Measurement zone & $\begin{array}{c}\text { Distance from } \\
\text { FL, }\end{array}$ & \multicolumn{7}{|c|}{ Chemical elements } \\
\cline { 3 - 8 } & & $\mathrm{C}$ & $\mathrm{Si}$ & $\mathrm{Mn}$ & $\mathrm{Cr}$ & $\mathrm{Ni}$ & $\mathrm{Fe}$ \\
\hline Weld, point 1 & & & & & & \\
\hline Weld, point 2 & 40 & 1.67 & 1.24 & 9.93 & 14.86 & 5.08 & Ball. \\
\hline Weld, point 3 & 30 & 2.36 & 0.86 & 5.61 & 17.7 & 6.88 & Ball. \\
\hline Fusion line, 4 & 35 & 1.98 & 0.94 & 6.41 & 18.07 & 7.18 & Ball. \\
\hline Fusion line, 5 & 0 & 2.02 & - & 9.87 & 5.76 & 2.36 & Ball. \\
\hline Fusion line, 6 & 0 & 1.82 & 1.07 & 10.46 & 7.49 & 2.73 & Ball. \\
\hline HAZ, 7 & 0 & 1.58 & 0.97 & 9.71 & 7.5 & 2.58 & Ball. \\
\hline HAZ, 8 & 12 & 2.49 & - & 10.58 & 1.57 & - & Ball. \\
\hline HAZ,9 & 15 & 2.54 & - & 13.69 & 2.14 & - & Ball. \\
\hline HAZ, 10 & 8 & 2.24 & 1.06 & 11.55 & 1.89 & - & Ball. \\
\hline HAZ, 11 & 26 & 1.94 & 1.11 & 11.73 & 1.62 & - & Ball. \\
\hline HAZ, 12 & 24 & 2.04 & 1.17 & 11.61 & 1.49 & - & Ball. \\
\hline
\end{tabular}
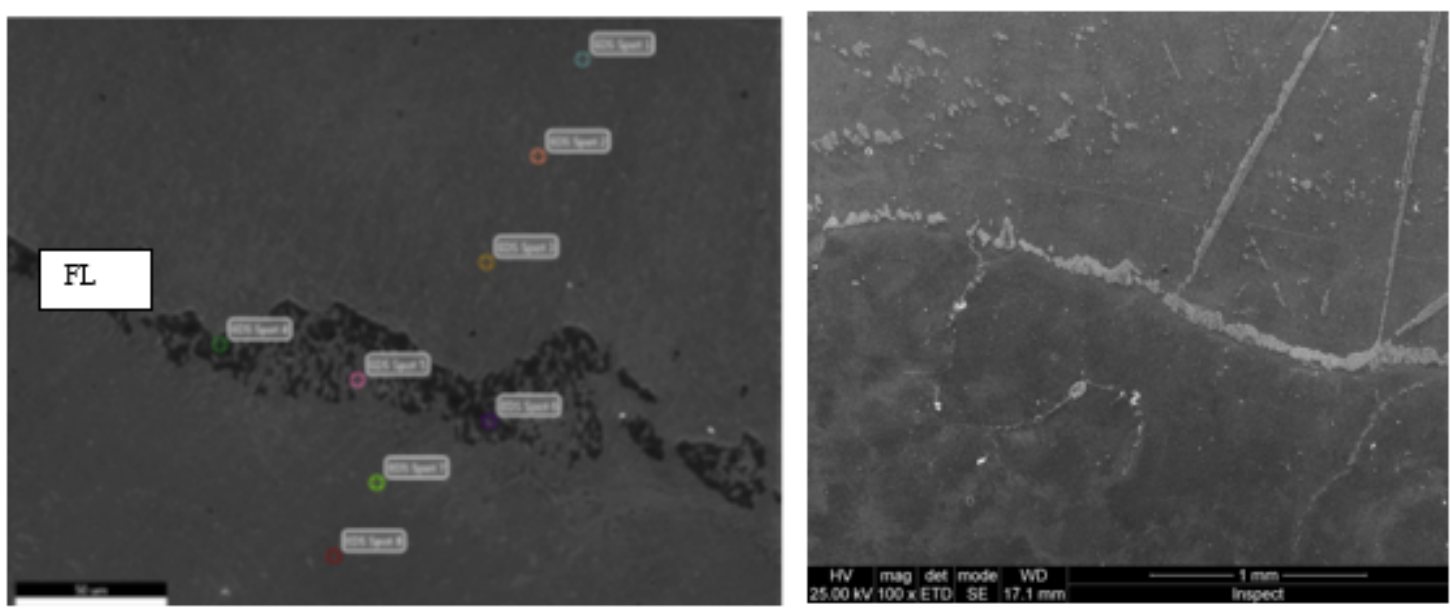

Fig. 10. Location of chemical analysis points, in crosssection, for the sample loaded with MF 7-250-KNP filler material 
The variation of the local chemical composition with distance from the fusion line is shown in a centralized manner in table 5.

From the values shown in table 5 it results that mutual diffusion of the chemical elements occurs from the welded deposit onto the support material and vice versa. The chromium content in the analyzed area of the welded drops from values such as: $14-18 \%$ wt. $\mathrm{Cr}$ towards 5-7\%wt. $\mathrm{Cr}$ in the fusion line area, then to 1.6$2 \%$ wt. $\mathrm{Cr}$ in the overheating area of the filler material. Also, the Ni content is higher in the weld comparatively with the standard chemical composition provided by the filler material producer.
In the case of the sample loaded with MF 7-250-KNP filler material, the distribution of the chemical elements on the fusion zone is shown in figures 10 and 11 , the local values of the chemical composition being summarized in table 6 . In this case, the reduction of the $\mathrm{Mn}$ content in the weld also is observed, due to the oxidation effects in the electric arc. The $\mathrm{Cr}$ diffusion in the base material extends over distances of 20 microns.

The chemical analysis on the crack's flanks of figure 12 led to the conclusion that chromium carbides were formed on the grain's boundaries during welding, which determined the development of cracks in the base material (fig. 13). As a result of the inappropriate thermal

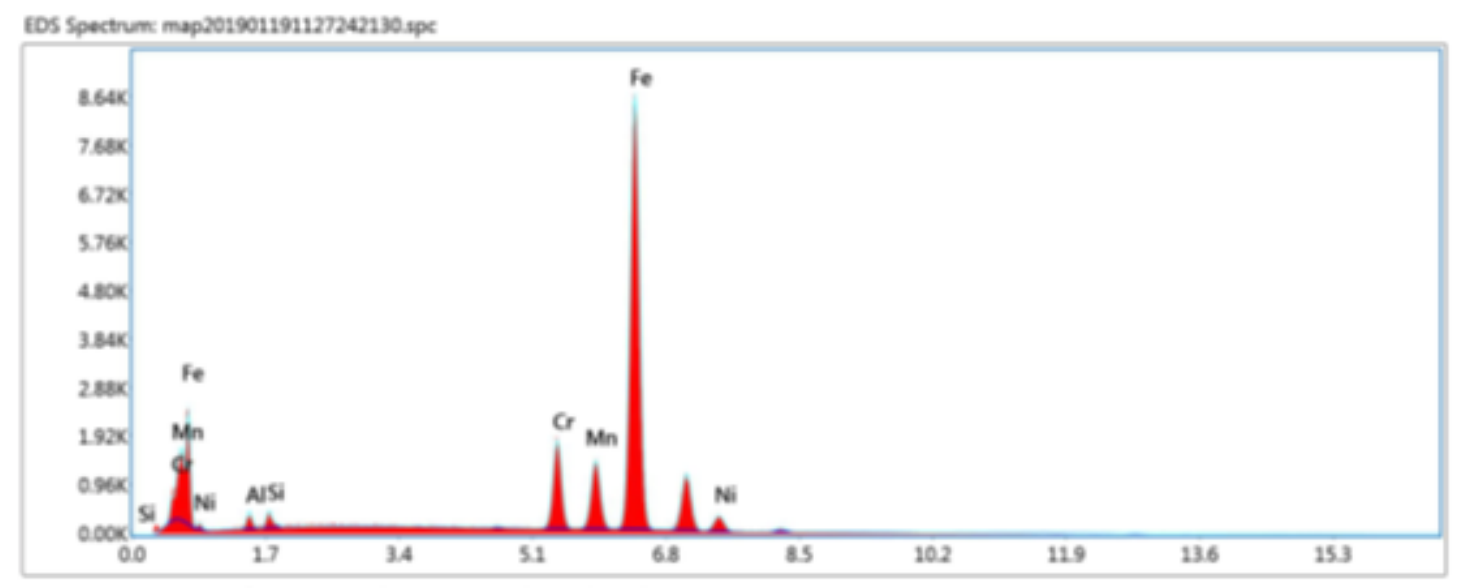

238 Cnts $1800 \mathrm{keV}$ Det flement Cas Lock Map/Line flements

Fig. 11. X-ray spectrum diagram associated to the micro-zone of figure 10

Table 6

CHEMICAL COMPOSITION IN DIFFERENT POSITIONS VERSUS FUSION LINE IN THE CASE OF MF 7-250-KNP FILLER MATERIAL, \%Wt

\begin{tabular}{|l|c|c|c|c|c|c|c|}
\hline Measurement zone & Distance from & \multicolumn{5}{|c|}{ Chemical elements } \\
\cline { 3 - 8 } & $\begin{array}{c}\text { FL, } \\
\mu \mathrm{m}\end{array}$ & $\mathrm{C}$ & $\mathrm{Si}$ & $\mathrm{Mn}$ & $\mathrm{Cr}$ & $\mathrm{Ni}$ & $\mathrm{Fe}$ \\
\hline Weld, point1 & 100 & 1.83 & 1.83 & 8.7 & 16.97 & 5.23 & Ball. \\
\hline Weld, point 2 & 70 & 2.61 & 1.96 & 7.65 & 13.91 & 4.63 & Ball. \\
\hline Weld, point 3 & 40 & 1.43 & 1.76 & 7.08 & 15.19 & 5.81 & Ball. \\
\hline Fusion line, 4 & 0 & 4.29 & 2.05 & 7.21 & 12.52 & 5.11 & Ball. \\
\hline Fusion line, 5 & 0 & 3.27 & 1.65 & 7.14 & 13.92 & 5.69 & Ball. \\
\hline Fusion line, 6 & 0 & 4.01 & 1.48 & 6.51 & 12.94 & 5.95 & Ball. \\
\hline HAZ, ? & 10 & 4 & 1.59 & 12.45 & 1.99 & 1.42 & Ball. \\
\hline HAZ, 8 & 20 & 3.6 & 1.64 & 11.16 & 2.08 & 0.83 & Ball. \\
\hline
\end{tabular}
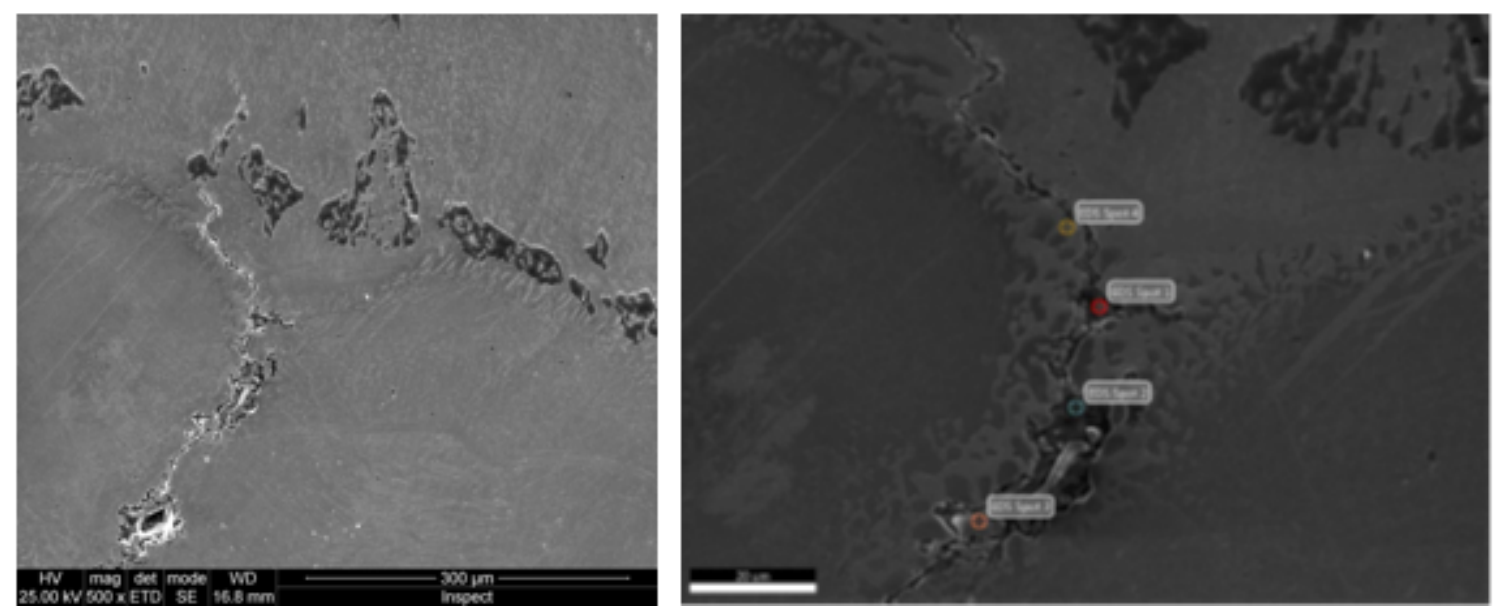

Fig. 12. Cracks formed in the base material extended towards the weld zone 


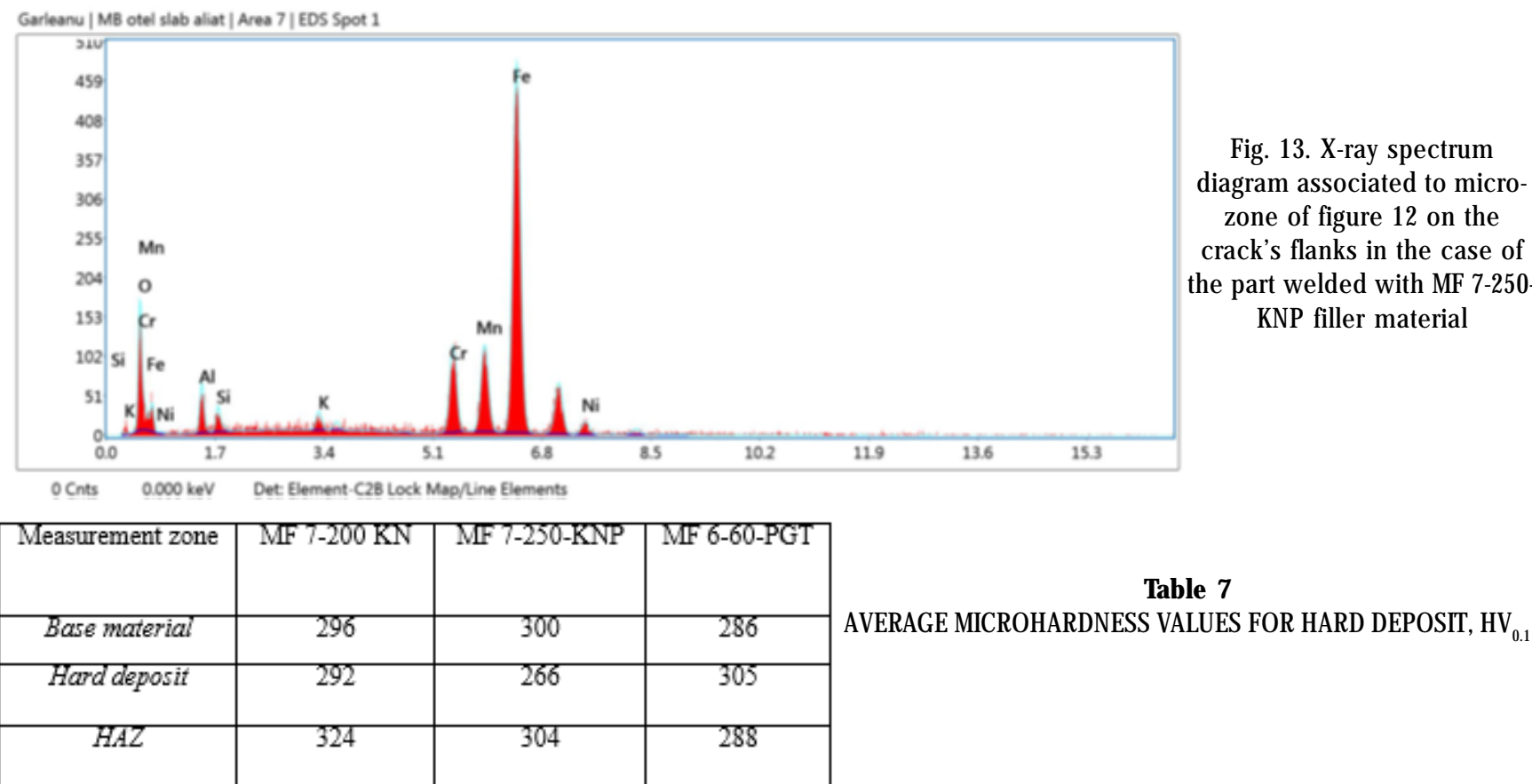

regime (lack of preheating) applied in this case, cracks were formed in $\mathrm{HAZ}$, which extended to the more ductile stitch, where they stopped at distances of about 100 microns. Thus, the concentration of $\mathrm{Cr}$ exceeded locally $20 \%$ wt.Cr on the crack's flanks (point 1, fig. 13a), while in the neighboring area (point 2, fig. 13a) is only $1.36 \%$ wt.Cr, as a result of the migration by diffusion of this element onto the grain's boundaries and of the formation of complex carbides.

\section{Microhardness}

In order to evaluate the effects of modification of the welding hardness and of the diffusion of the chemical elements in the welding interface area, hardness measurements were performed on the base metal, hard deposit highly alloyed with $\mathrm{Cr}$ and $\mathrm{Mn}$, on the welding interface area and in the heat affected zone of base material. The measurements were made using a Shimadzu HMV 2T microhardness apparatus, in line, with marks distances of about $500 \mu \mathrm{m}$. The values of micro-hardness $\mathrm{HV}_{0.1}$, determined with the value of the 10 s pressing time, are shown in table 7.

\section{Conclusions}

The parts made of steel highly alloyed with $\mathrm{Mn}$ can be refurbished by hard loading using the full-wire GMAW welding process without the occurring of imperfections, if the thermal regime values (preheating) are met and an appropriate chemical composition is selected to comply with the operational requirements.

In the case of the steel parts with high Mn content (over $13 \%$ wt.Mn), which are required for impact and severe abrasion, it is not recommended the association in the chemical composition of the welding filler material of elements as $\mathrm{Cr}$ and $\mathrm{Mn}$, at values over 14\%wt. Firstly, Mn generates an austenitic hardened microstructure in operation, similar to that of the base material, but this effect is counteracted by $\mathrm{Cr}$, which stabilizes the ferrite and diminishes the austenitic ratio, and so the hardness of the welding being just below that of the base material. In addition, cracks were formed in the areas under the weld due to internal stress and to the formation of hard compounds (chromium carbides). The choice of a filler material highly alloyed with $\mathrm{Cr}$ (over $9 \%$ wt.Cr) is not appropriate for the case analyzed as it has led to a fragile welding susceptible to cracks under the weld.

Although the hardness measured in welding was not very high in any of the situations analyzed in comparison to the base material, its values can be increased or doubled in operation, leading to an increase in the useful life of 1.5 to 2 times compared to the molded parts, simultaneously with reducing the costs by $25-40 \%$ compared to the replacement with new parts.

Acknowledgements: Research contract no. 23803 / 22.11.2018 Reconditionarea prin incarcare prin sudare a unor ciocane concasor tip WEDAG/ Refurbishment through loading by welding of some WEDAG type crushing hammers, between University Politehnica of Bucharest (UPB - CNCPST - OPTIMUM) and S.C. CANAD SYSTEM IMPEX S.R.L.

\section{References}

1.BUCHELY M.F., GUTIERREZ J.C., LEON L.M., TORO A., The effect of microstructure on abrasive wear of hardfacing alloys, Wear, no. 259, 2005, p.52-61.

2.VLADUTOIU L., VLADUT V., VOICULESCU I., MATACHE M., RADU 0., BIRIS. S, VOICEA I., PARASCHIV G., ATANASOV A., USENKO M., Increasing Agricultural Machinery Active Parts Durability by Hardening, Book Series: Actual Tasks on Agricultural Engineering-Zagreb, 43, 2015, p.153-164.

3.BINCHICIU E.F., FLESER T., VOICULESCU I., GEANTA V., Composites deposits developed by w elding on horizontal mill hammers, Advanced Materials Research, Tech Publications, Switzerland, 1146, 2018, p.2731.

4.VOICULESCU, I., GEANTA, V., STEFANOIU, R., PATROI, D., BINCHICIU,

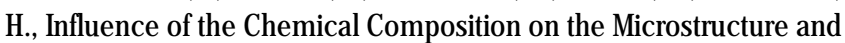
Microhardness of AlCrFeCoNi High Entropy Alloy, Rev. Chim. (Bucharest), 64, no. 12, 2013, p.1441-1444.

5.VOICULESCU I., GEANTA V., VASILE I.M., STEFANOIU R., TONOIU M., Characterisation of weld deposits using as filler metal a high entropy alloy. J ournal of Optoelectronics and Advanced Materials, 15, no. 7-8, 2013, p.650 - 654.

6.PAVALACHE A.C., VOICULESCU I., IORDACHESCU D., VASILE G., STANCIU E.M., APOSTOL G., Obtaining of Metal Matrix Composites Layers by Laser Cladding, Metalurgia International, 16, Special Issue no. 5, 2011, p.121-124. 
7.STANCIU E.M., PASCU A., TIEREAN M.H., VOICULESCU I., ROATA I. C., CROITORU C. \& HULKA I., Dual Coating Laser Cladding of $\mathrm{NiCrBSi}$ and Inconel 718, Materials and Manufacturing Processes, 31, issue 12, 2016, p.1556-1564.

8.GEANTA, V., VOICULESCU, I., MILOSAN, I., ISTRATE, B., MATES, I. M., Chemical Composition Influence on Microhardness, Microstructure and Phases Morphology of $\mathrm{Al}$ CrFeCoNi High Entropy Alloys, Rev. Chim. (Bucharest), 69, no. 4, 2018, p.798-801.

9.GEANTA, V., VOICULESCU, I., ISTRATE, B., VRANCEANU, D.M., CIOCOIU, R., COTRUT, C.M., The Influence of Chromium Content on the Structural and Mechanical Properties of AlCrxFeCoNi High Entropy Alloys, International J ournal of Engineering Research in Africa, 37, 2018, p.23-28.

10.BESLIU, M. M., VOICULESCU, I., SOLOMON Gh., Effects of Dilution on Weld Overlays Realized with Flux-cored Arc Welding (FCAW) Process Using 309LV Filler Metal on the S235] R Steel, UPB Sci. Bull. Series B-Chemistry and Materials Science,79, Issue: 1, 2017, p.173182.

11.PAVALACHE A.C., VASILE I.M, STANCIU, E.M., VOICULESCU I., Case Study about the Effect of Measurement Parameters Values on the Microhardness Results, Book Group, Conference: IEEE International Workshop on Advanced Methods for Uncertainty Estimation in Measurement, Bucharest, ROMANIA, 2009 p.54-57.

12.ZAHIRI R., SUNDARAMOORTHY R., LYSZ P., SUBRAMANIAN C., Hardfacing using ferro-alloy powder mixtures by submerged arc welding, Surface \& Coatings Technology, 260, 2014, p.220-229.

13.VENKATESH B., SRIKER K., PRABHAKAR V.S.V., Wear characteristics of hardfacing alloys: state-of-the-art, Procedia Materials Science, 10, 2015, p.527 - 532.

14. SRIKARUN B., MUANGJ UNBUREE P., The effect of iron-based hardfacing with chromium powder addition onto low carbon steel, Materials Today: Proceedings 5 2018, p.9272-9280.

15. GARLEANU G., POPOVICI V., GARLEANU D., LUCHIAN C., Modeling by Finite Element Method of Thermal Field when Coating with Stellite Welding of Valve type Parts", Applied Mechanics and Materials, 371, 2013, p.260-264.

16. GARLEANU D., GARLEANU G., BORDA C., ARSENE D., The New Repair Technology the Spiral Heat Exchangers, International Journal of Scientific \& Engineering Research (IJ SER), 7, Issue 10, 2016, p.373378.
17.OLSON D.L., Prediction of Austenitic Weld Metal Microstructure and Properties, Welding Research Supplement, 1985, p.281-295-s. 18.GEANTA, V., VOICULESCU, I., STEFANOIU, R., BINCHICIU, H., NEGRIU, R.M. Researches regarding the establishment of the optimal chemical composition of the centrifugal crushers' retention sills. Metalurgia International, Special Issue, no. 1, 2013, p.19-23.

19.TIHANOV-TANASACHE, D., FLOREA, C., BINCHICIU, E., GEANTA, V. Armor with hyper-entropic behavior and self-protection. Applied Mechanics and Materials, Vol. 656, 2014, p. 30-36.

20.GEANTA, V., VOICULESCU, I., BINCHICIU, H., VIDA-SIMITII., JUMATE, N., STEFANOIU, R. Steel structures hard-facing using composite core electrode, Welding in the World, Croatia 2007, p. 749-756. 21.BINCHICIU, A., VOICULESCU, I., GEANTA, V., BINCHICIU, H., STEFANOIU R., IOVANAS, D., BINCHICIU, E., NEGRIU, R.M. Blindaj antiuzura si procedeu de fabricatie (Anti-lock armor and manufacturing process) Patent nr. RO 125760/30.12.2011.

22.VOICULESCU, I., GEANTA, V., IONESCU, M. Effects of heat treatments on the microstructure and microhardness of AlxCrFeNiMn alloys, The Annals of Dunarea de Jos University of Galati, fascicle XII, Vol. 26, 2015, p.5-11.

23.IOVANAS D.M., BINCHICIU H., VOICULESCU I., BINCHICIU E.F., Factors that influence the quality constant of the manufacturing process for asphalt milling knifes, 8-th International Conference on Manufacturing Science and Education (MSE 2017) MATEC Web of Conferences, Vol. 121, 2017, Article Number: UNSP 03010.

24.VOICULESCU, I.; GEANTA, V.; STEFANOIU, R; COTRUT, C.; CIOCOIU, R.; IONESCU, M., Mechanical and Microstructural Characterization of a New Corrosion Resistant Stainless Steel, EUROINVENT ICIR 2018, IOP Conference Series-Materials Science and Engineering, Vol. 374, Article Number: UNSP 012018.

25.VOICULESCU I., GEANTA V., C.C. RUSU, O. MIRCEA, L.R. MISTODIE, E. SCUTELNICU, Research on the Metallurgical Behaviour of X70 Steel subjected to Multi-Wire Suberged Arc Welding, The Annals of Dunarea de J os University of Galati, Fascicle XII, Welding Equipment and Technology, Vol. 27 (Year XXVII) 2016, p.38-46

$\overline{\text { Manuscript received: } 29.11 .2018}$ 